\title{
The Effect of Flipped Classroom on the Academic Achievement and Attitude of Higher Education Students
}

\author{
Duygu Sağlam ${ }^{1} \&$ Ali Arslan ${ }^{2, *}$ \\ ${ }^{1}$ School of Foreign Languages, Bulent Ecevit University, Zonguldak, Turkey \\ ${ }^{2}$ School of Eregli Education, Bulent Ecevit University, Zonguldak, Turkey \\ *Correspondence: School of Eregli Education, Bulent Ecevit University, Zonguldak, Turkey. E-mail: \\ aliarslan.beun@gmail.com \\ *This study is a summary of the MA thesis entitled "The Effect of Flipped Classroom Model on the Academic \\ Achievements and Attitudes of Students in English Language Teaching" written by the first author under the \\ supervision of the second author.
}

Received: July 24, 2018

Accepted: August 10, $2018 \quad$ Online Published: August 24, 2018

doi:10.5430/wje.v8n4p170

URL: https://doi.org/10.5430/wje.v8n4p170

\begin{abstract}
This study aims to search the effect of flipped classroom on students' learning a new grammar structure and their attitudes towards the English course. The study was carried out for 6 weeks with 56 students studying in five different preparatory classes at a black sea region university's foreign languages school in the fall term of 2015-2016 academic year. The design of the study was 'non-equivalent control group design' which is one of quasi-experimental designs. Data were gathered with help of an achievement test and an attitude scale. Flipped classroom model was applied in the experimental group while traditional instruction was applied in the control group. At the end of the study, it was concluded that flipped classroom had medium effect on students' academic achievements and attitudes comparing to traditional instruction.
\end{abstract}

Keyword: flipped classroom, academic achievement, attitude

\section{Introduction}

The importance given to the needs and expectations of the individuals is increasing. It is inevitable to develop and change in every field of life with the rapid increase of the technology and the developments in the future. In particular, with the widespread use of internet, computers and mobile devices, great improvements have been achieved in accessing and producing information. Education is a constantly changing and evolving field to meet the needs and expectations of students. The developments experienced in technology are reflected in the field of education and expectations of students and education are also differentiated. According to Naimie, Siraj, Abuzaid and Shagholi (2010), the most accurate and successful learning environments are up-to-date in the twenty-first century developments and the axis of information age, and suggestions should always be made to develop learning environments via traditional or internet learning. The main aim of education is to provide higher order learning. In order to reach the high levels of learning, teachers organize understandable, easy to follow and interesting lessons according to the needs and abilities of the learners. Today's students learn by doing instead of listening passively and they involve the learning process. Traditional education is not always able to meet these expectations, so educators diversify their learning environments by taking advantage of the various tools provided by the age of technology. Millenial students prefer to be easily constantly connected with information, to deal with multitasking and they are intolerant for delaying (Mcmahon \& Pospisil, 2005). So, most educators have adopted active learning strategies to engage these students in school activities (Roehl, Reddy \& Shannon, 2013).

The history of computer use in education began with the use of computers for administrative purposes in the United States in the late 1950s, in some universities. With the introduction of lower cost computers in the 1960s and 1970s, projects related to educational applications began to be developed such as the IBM 1500, PLATO and TICCIT systems (Odabaş1, 1998). In Turkey, the transition to computer-aided education has been a little late. The Ministry of 
National Education was interested in using computers in education in parallel with developments in the Western world and initiated the Computer-Assisted Instruction Project in 1984. The General Directorate of Educational Technologies, established in 1998, was actually replaced by the General Directorate of Computer Education and Services. The Department of Educational Information Technology (EBIT), which works under this general directorate, has an important place in the introduction of new information technologies into schools (Yaşar, 1998). The task of this unit is to plan and implement basic computer training and computer aided education in all types and levels of schools. Within this scope, projects such as the development of computer software and the establishment of school information networks are being prepared and carried out (Akkoyunlu \& İmer, 1998). Students learn in many different ways such as listening, note-taking, picturing, seeing and visualizing (Naimie et al., 2010). Therefore, many schools set up computer laboratories to provide new and permanent information to their students and to improve their listening, speaking, reading, testing and communication skills (Yağcioğlu, 2008). The possibilities for creating rich multi-media (audio-video) are some of the key factors for supplemantary activities for personal research, practice, individual access, personalization, interactive learning, course management, unlimited time and mixed learning. Some new skills, such as multicultural communication, can be developed by combining traditional learning with computer-assisted instruction through appropriate methods and pedagogical approaches (Seljan, Banek, Špiranec, \& Lasić-Lazić, 2006).

Today, students in higher education especially spend their time using technology as much as they have never had. Therefore, various methods have been developed by taking into account the importance given to technology and individual in the field of education, and the student has taken the focus on the training process. As a result of individualization, it is inevitable for students to realize their own learning responsibilities, and the efficient use of time outside the classroom becomes compulsory. The use of technology is beneficial for efficient use of both in-class and out-of-class time. Flipped classroom, a combination of technology and student-centered learning, emerges as a method of increasing classroom and out-of-class productivity. Briefly, the flipped classroom is a teaching model in which classroom-based laboratory activities, problem solving, group work, etc. are taught with traditional methods by flipping the process of making related homework outside the learning environment (Roehl, Reddy \& Shannon, 2013).

The flipped classroom is based on constructivist learning theory (Bishop \& Verleger, 2013). For this theory, learners constructs their own meaning depending on already existing knowledge. The students actively involve the learning process. In this process, instead of giving direct information to learners, they prepare an appropriate learning environment in which they build their knowledge (Kauchak \& Eggen, 2003). In the flipped classroom, the out-of-class learning process is based entirely on self-regulated learning. Classroom learning activities are high level cognitive activities using active learning techniques and students interact with each other (Roehl, Reddy \& Shannon, 2013).

The flipped classroom is a process that traditionally narrates and transforms the process of making homework at home, flipping the way the student learns at home and collaborates with classroom time. The flipped classroom is a learning model in which face-to-face learning is modeled for online environments and blended with distance education (Demiralay, 2014). This concept is gaining popularity due to the prevailing nature of the tools like iTunes, Youtube, and Learning Management Systems are used to achieve 'the opposite' (Johnson \& Renner, 2012). The starting point for the flipped classroom model was in 2007, Jonathan Bergman and Aaron Sams, two chemistry teachers living in Colorado, began their studies with students who often missed classes to participate in competitions, games or other organizations. These teachers began to record their lessons, presentations and slide presentations and put them on Youtube for the reach of their students. On this page, face-to-face classes were developed by adding questions and quizzes from time to time, keeping videos in different versions. Some flipped classroom models include audio recordings instead of video (Wolff \& Chan, 2016). The flipped classroom model is a new pedagogical method based on active and group-based problem-solving activities in the classroom, with simultaneous non-simultaneous video tutorials and homework exercises (Bishop \& Verleger, 2013). Flipped classroom provides opportunity for students to learn a content according to their learning style and at their own pace according to their needs (Muldrow, 2013; Strayer, 2007).

Johnson and Renner (2012) investigated the effects of the traditional learning model and the flipped classroom model on the transfer of the computer applications course. Repeatedly changing mixed method was used as research design. It was held in the course of computer applications with 26 primary education students in the quarter of 2011-2012 academic year. As a result of the research, it was concluded that there is no significant difference in the analysis of the courses given by the flipped classroom model and the traditional learning model. Davies, Dean and Ball (2013) aimed to determine how technology could be used to teach technological skills in their work and to compare the 
benefits of flipping the class in terms of student achievement and satisfaction in entry level table-level college compared to traditional training methods. In this study, semi-experimental quasi-experimental design was used. The study was conducted in Brigham Young University for 5 weeks in 2 separate periods over 188 students taking the introductory information systems course in the 2012 academic year. In the first semester the participants' course was taught as a traditional classroom and in the second semester the class was applied with flipped classroom model. As a result of the research, it has been seen that the flipped classroom model facilitates learning and the lessons become more effective and motivating. Yestrebsky (2015) aimed to determine the effectiveness of flipped classroom model in the first-year chemistry course of a research university. The research was conducted at the University of Central Florida in the second semester of a general and second-year general chemistry course of 415 and 320 students, mainly science and engineering students. While the course was taught by traditional teaching methods, the experiment group used the flipped classroom model. As a result of the assessment of the final grades of the students, it was observed that the high score group was mostly from the experimental group and the experimental group students found the application useful and watch the online applications repeatedly.

When studies are examined, it is seen that there is not enough study on the flipped classroom model. In studies examining the effectiveness of the flipped classroom model, dependent variables were mostly academic achievement, students' attitudes towards the course and motivation levels. In this study, the academic achievement and attitudes of the students were studied as a dependent variable and the effects of the application of the flipped classroom model on the students were tried to be determined in comparison with the traditional method. The flipped classroom model is used to individualize learning out of class and reinforce and support classroom practices. It is expected that this study will provide information on the applicability of the flipped classroom model in English classes.

The aim of this study is to examine the effect of the flipped classroom model on academic achievement and attitudes of higher education students in English language instruction.

\section{Method}

\subsection{Design}

This study was conducted with non-equivalent control group design which is one of quasi-experimental designs. In this design, experimental and control groups are not assigned randomly. They are selected from already existing groups (Gay \& Airasian, 2000). Experimental studies investigate causal relations between dependent and independent variables. In this study, the teaching models (flipped classroom and traditional) are independent variable; English academic achievement and the attitudes towards English course are dependent variables. Before the experimental process, the achievement test and attitude scale was applied as pre-test to experimantal and control groups. During the experimental process, the control group was not intervened while the experimental group is being taught according to the flipped classroom model. At the end of the experimental process, achievement test and attitude scale were applied as a post-test to the experimental and control groups.

\subsection{Participants}

The study was carried out on a total of 56 students attending a black sea region university's foreign language school in the fall semester of 2015-2016 academic year. The groups were selected from equal classes. Experimantal groups (P 41, P 39 and P 19 classes) and control groups (P 8 and P 14 classes) were selected randomly from among the classes learning the same subjects in the same way up to the time of the experiment. Academic achievement test and attitude scale were conducted as a pre-test in order to determine whether the the experiment and control groups were equivalent at the begining of study. It was found that two groups were equal in terms of academic achievement $\left(\mathrm{t}_{(54)}=0,040 ; \mathrm{p}>0,05\right)$ and attitude towards English course $\left(\mathrm{t}_{(54)}=0,077 ; \mathrm{p}>0,05\right)$.

\subsection{Instruments}

\subsubsection{Academic Achievement Test}

Academic achievement test, redacted by 4 English instructors and two curriculum and instruction specialists, was formed by the researchers to measure students' academic achievement on the subject - past tense in grammar courses. Trial form containing 54 items was implemented to 188 students attending upper level classes as a pilot study to detect the difficulty and distinguishing indices of each item. The items with low distinguishing index were eliminated and the number of items was a total of 45 items. While mean of item difficulty index was 0,43; mean of item distinguishing index was 0,55 . The Cronbach's Alpha coefficient was calculated as 0,90 . These values indicate that this test measures validly and reliably academic achievement of students. 


\subsubsection{Scale of Attitude towards English Course:}

To measure students' attitudes towards the English course, Aiken (1979)'s scale of attitude towards English course which was adjusted to the English courses after rendering Turkish by Tunç (2003), was implemented to the students. The scale was a 5 point likert type and included 24 items. The Cronbach's Alpha coefficient of the scale was calculated as 0,90 for this study. It was performed as a pre-test and post-test for experimental and control groups.

\subsection{Data Analysis}

To decide statistical analysis method, the skewness and kurtosis values of the pre-test and post-test scores of the experimental and control groups were examined to determine whether the data had a normal distribution. It was observed that skewness and kurtosis values were between -2 and +2 (George \& Mallery, 2016). For this reason, parametric statistics were used in the analysis of data. In the study, paired samples $t$ test was used in order to compare the pre-test and post-test scores of experimental and control groups and independent samples $t$ test was used in the comparison of groups gain scores. For effect size of these differences, $\boldsymbol{\eta}^{\mathbf{2}}$ were calculated. $\boldsymbol{\eta}^{\mathbf{2}}$ values of interpreted as $0-0,01$ is no effect, $0,01-0,06$ is small effect, $0,06-0,14$ is medium effect and 0,14-1,00 is large effect (Green, Salkind \& Akey, 2000). In the analysis of the data, "SPSS 19.0 for Windows" package program was used. Data were interpreted in $\% 95$ confidence interval.

\section{Results}

This study's purpose was to elicit the effect of flipped classroom on academic achievement and attitude towards English course. So, pre-test and post-test means of the experimental and control groups were compared to decide effect of methods applied in two groups for academic achievements and attitudes. Results were compared with Paired samples t test and presented in table 1.

Table 1. Paired Samples t-Test

\begin{tabular}{cccccccccccccc}
\hline \multicolumn{1}{c}{ Experimental Group } & \multicolumn{10}{c}{ Control Group } \\
\hline \multicolumn{1}{c}{ Tests } & $\mathbf{N}$ & $\mathbf{M}$ & SD & $\mathbf{t}$ & $\mathbf{p}$ & $\mathbf{\eta}^{\mathbf{2}}$ & $\mathbf{N}$ & $\mathbf{M}$ & SD & $\mathbf{t}$ & $\mathbf{p}$ & $\boldsymbol{\eta}^{\mathbf{2}}$ \\
\hline Ach. & Pre & 29 & 13,89 & 8,79 & \multirow{2}{*}{$6,27^{*}$} & 0,00 & 0,58 & 27 & 13,81 & 5,99 & \multirow{2}{*}{$4,03^{*}$} & 0,00 & 0,38 \\
& Post & 29 & 27,10 & 9,86 & & & & 27 & 19,51 & 8,62 & & & \\
Att. & Pre & 29 & 3,90 & 0,41 & $4,32^{*}$ & 0,00 & 0,40 & 27 & 3,89 & 0,59 & 0,026 & 0,976 & - \\
& Post & 29 & 4,15 & 0,32 & & & & & & \\
\end{tabular}

${ }^{*} \mathrm{p}<0,05$

Table 1 indicates that there is significant difference between experimental group students' academic achievement pre-test scores $(\mathrm{M}=13,89$; $\mathrm{SD}: 8,79)$ and post-test scores $(\mathrm{M}=27,10$; $\mathrm{SD}: 9,86)$ in favor of post-test scores $\left(\mathrm{t}_{(28)}=6,27\right.$; $\mathrm{p}<0,05)$. $\mathbf{\eta}^{\mathbf{2}}$ of this difference was calculated as 0,58 . This value indicates that flipped clasroom has large effect and predicts $58 \%$ of academic achievement of students. Smilarly, there is significant difference between control group students' academic achievement pre-test scores $(\mathrm{M}=13,81 ; \mathrm{SD}=5,99)$ and post-test scores $(\mathrm{M}=19,51 ; \mathrm{SD}=8,62)$ in favor of post-test scores $\left(\mathrm{t}_{(26)}=4,03 ; \mathrm{p}<0,05\right)$. $\mathbf{\eta}^{2}$ of this difference was calculated as 0,38 . This value indicates that flipped clasroom has large effect and predicts $38 \%$ of academic achievement of students.

The attitude is second dependent variable of this study. Table 1 indicates that there is significant difference between experimental group students' attitude pre-test scores $(M=3,90 ; S D=0,41)$ and post-test scores $(M=4,15 ; S D$ : 0,32$)$ in favor of post-test scores $\left(\mathrm{t}_{(28)}=4,32 ; \mathrm{p}<0,05\right)$. $\mathbf{\eta}^{2}$ of this difference was calculated as 0,40 . This value indicates that flipped clasroom has large effect and predicts \% 40 of attitudes of students. But, there isn't significant difference $\left(\mathrm{t}_{(26)}=0,026 ; \mathrm{p}>0,05\right)$ between control group students' attitude pre-test scores (M=13,81; SD: 5,99) and post-test scores $(\mathrm{M}=19,51 ; \mathrm{SD}: 8,62)$.

At the same time, academic achievement and attitude gain score of the experimental and control groups were compared with independent samples t-test. The findings were presented in Table 2. 
Table 2. Independent Samples t-Test

\begin{tabular}{cccccccc}
\hline Test & Groups & N & M (GS) & SD & t & p & 耳2 \\
\hline Ach. & Exp. & 29 & 13,21 & 11,33 & \multirow{2}{*}{$2,91^{*}$} & \multirow{2}{*}{0,005} & 0,13 \\
& Con. & 27 & 5,70 & 7,35 & & & \\
Att. & Exp. & 29 & 0,257 & 0,32 & $2,34^{*}$ & 0,02 & 0,09 \\
& Con. & 27 & 0,002 & 0,48 & & \\
\hline
\end{tabular}

${ }^{*} \mathrm{p}<0,05$

Table 2 indicates that there is significant difference between the experimental group students' academic achievement gain scores $(M=13,21 ; \mathrm{SD}=11,33)$ and the control group students' academic achievement gain scores $(\mathrm{M}=5,70$; $\mathrm{SD}=7,35)$ in favor of experimental group $\left(\mathrm{t}_{(44)}=2,91 ; \mathrm{p}<0,05\right) . \mathbf{\eta}^{\mathbf{2}}$ of this difference was calculated as 0,13 . This value indicates that flipped clasroom has medium effect on academic achievement comparing to traditional instruction.

Similarly, it indicates that there is significant difference between the experimental group students' attitude gain scores $(\mathrm{M}=0,25 ; \mathrm{SD}=0,32)$ and the control group students' attitude gain scores $(\mathrm{M}=0,002 ; \mathrm{SD}=0,48)$ in favor of experimental group $\left(\mathrm{t}_{(44)}=2,34 ; \mathrm{p}<0,05\right)$. $\mathbf{\eta}^{2}$ of this difference was calculated as 0,09 . This value indicates that flipped clasroom has medium effect on attitude towards English course comparing to traditional instruction.

\section{Conclusion and Discussion}

The purpose of this study was to investigate the effect of flipped classroom model on university students' achievements and attitudes towards the English course. According to the achievement test findings of the study, the flipped classroom had more increased academic achievement than the traditional instruction in English courses. Also, the effect size value indicated that flipped classroom had medium effect on academic achievement comparing to traditional instruction. Similarly, Alsancak Sırakaya (2015), Boyraz (2014), Ekmekçi (2014), Overmyer (2014) and Turan, (2015); found that flipped classroom was further improved when compared to the traditional teaching method.

Attitude was second dependent variable in this study. The students who had the lessons via the flipped classroom model had more increased attitude than the traditional instruction in English courses. Also, the effect size value indicated that the flipped classroom had medium effect on attitude towards English course comparing to traditional instruction. In the study of Davies, et al. (2013), it was aimed to find out the uses of the flipped classroom by comparing it to traditional way in terms of student achievement and satisfaction. As a result of the study, it was seen that the flipped classroom model facilitates learning and the lessons become more effective and motivating. As it was concluded in Turan and Göktas (2015)'s study that the students had very positive opinions about the flipped classroom. They stated that the flipped classroom is a fun and flexible method that enhances the learning permanence and facilitates learning. Through the flipped classroom the students become individualized and take their own learning responsibilities, enabling them to work wherever and whenever they want. Similarly, Strayer (2012) has found that students who learns by flipped classroom experienced more innovation and cooperation in their learning process than students who learns by traditional method.

This study was conducted quantitatively. Qualitative data can be collected by using different instruments in other studies. This case can provide deeper meaning about process. There were two dependent variables in this study. It can be examined that the effect of flipped classroom on other dependent variable such as motivation, self-efficacy, self-worth in addition to academic achievement and attitude. By using flipped classroom model in English lessons, the students' academic achievements and attitudes increased in this study. So, studies can be done to reveal the usefulness of the flipped classroom model in other courses in higher education. Studies on the effectiveness of the flipped classroom model on achievement and attitudes in primary and secondary education can be made. Also, a study can be made based on the influence of the gender variable of the flipped classroom model.

\section{References}

Aiken, L. R. (1979). Attitudes toward maths and science in Iranian schools. School Science and Maths, 76, 229-234. https://doi.org/10.1111/j.1949-8594.1979.tb09490.x

Akkoyunlu, B., \& İmer, G. (1998); Türkiye'de eğitim teknolojisinin görünümü. Çağdaş Eğitimde Yeni Teknolojiler, Anadolu Üniversitesi, Eskişehir, 160-168.

Alsancak Sırakaya, D. (2015). Tersyüz sınıf modelinin akademik başarı, öz-yönetimli öğrenme hazırbulunuşluğu ve 
motivasyon üzerine etkisi. Doktora Tezi. Gazi Üniversitesi Eğitim Bilimleri Enstitüsü.

Bishop, J. L., \& Verleger, M. A. (2013). The flipped classroom: A survey of the research. In ASEE National Conference Proceedings, Atlanta, GA, 30(9), 1-18.

Boyraz, S. (2014). İngilizce öğretiminde tersine eğitim uygulamasının değerlendirilmesi. Yüksek Lisans Tezi, Afyon Kocatepe Üniversitesi.

Davies, R. S., Dean, D. L., \& Ball, N. (2013). Flipping the classroom and instructional technology integration in a college-level information systems spreadsheet course. Educational Technology Research and Development, 61(4), 563-580. https://doi.org/10.1007/s11423-013-9305-6

Demiralay, R. (2014). Evde ders okulda ödev modelinin benimsenmesi sürecinin yeniliğin yayılımı kuramı çerçevesinde incelenmesi. Doktora Tezi, Gazi Üniversitesi.

Ekmekçi, E. (2014). Flipped writing class model with a focus on blended learning. Doktora Tezi, Gazi Üniversitesi.

Gay, L. R., \& Airasian, P. (2000). Educational research: Competencies for analysis and experience. New Jersey: Prentice Hall.

George, D., \& Mallery, P. (2016). IBM Statistics 23 Step by step: A simple guide and reference. Routledge.

Green, S. B., Salkind, N. J., \& Akey, T. M. (2000). Using SPSS for windows. Analyzing and understanding data. New Jersey: PracticeHall.

Johnson, L. W., \& Renner, J. D. (2012). Effect of the flipped classroom model on a secondary computer applications course: student and teacher perceptions, questions and student achievement. Dissertation. University of Louisville, Kentucky.

Kauchak, D. P., \& Eggen, P. D. (2003). Learning and teaching: Research based methods. New York: Allyn Bacon.

McMahon, M., \& Pospisil, R. (2005). Laptops for a digital lifestyle: Millennial students and wireless mobile technologies. Proceedings of the Australasian Society for Computers in Learning in Tertiary Education, 2, 421-431.

Muldrow, K. (2013). New approach to language instruction- Flipping classroom. The Language Educator, 11, 28-31.

Naimie, Z., Siraj, S., Abuzaid, R. A., \& Shagholi, R. (2010). Hypothesized learners' technology preferences based on learning style dimensions. TOJET: The Turkish Online Journal of Educational Technology, 9(4), 83-93.

Odabaşı, F. (1998). Bilgisayar destekli eğitim. T.C. Anadolu Üniversitesi Yayınları Açıköğretim Fakültesi Yayınları, 1059 (582), Eskişehir, 135-147.

Overmyer, G. R. (2014). The flipped classroom model for college algebra: Effects on student achievement. Dissertation.Colorado State University Fort Collins, Colorado.

Roehl, A., Reddy, S. L., \& Shannon, G. J. (2013). The flipped classroom: An opportunity to engage millennial students through active learning. Journal of Family and Consumer Sciences, 105(2), 44. https://doi.org/10.14307/JFCS105.2.12

Seljan, S., Banek Zorica, M., Špiranec, S., \& Lasić-Lazić, J. (2006). CALL (computer-assisted language learning) and distance learning. Proceedings of the 29th International convention MIPRO, 145-151.

Strayer, J. F. (2007). The effects of the classroom flip on the learning environment: A comparison of learning activity in a traditional classroom and a flip classroom that used an intelligent tutoring system. Doctoral dissertation, The Ohio State University.

Strayer, J. F. (2012). How learning in an inverted classroom influences cooperation, innovation and task orientation. Learning Environments Research, 15, 171-193. https://doi.org/10.1007/s10984-012-9108-4

Tunç, S. Ö. (2003). Use of Language Learning Strategies in relation to Student Characteristics at Başkent University. Master of Science Thesis, METU The Graduate School of Social Sciences.

Turan, Z. (2015). Ters yüz slnıf yönteminin değerlendirilmesi ve akademik başarı, bilişsel yük ve motivasyona etkisinin incelenmesi. Doktora Tezi, Atatürk Üniversitesi.

Turan, Z., \& Göktaş, Y. (2015). Yükseköğretimde yeni bir yaklaşım: öğrencilerin ters yüz sınıf yöntemine ilişkin görüşleri. Yüksekögretim ve Bilim Dergisi/Journal of Higher Education and Science, 5(2), 156-164. https://doi.org/10.5961/jhes.2015.118 
Wolff, L. C., \& Chan, J. (2016). Flipped classrooms for legal education. Springer.

Yağcığlu, Ö. (2008). İngiliz Dili eğitiminde web sitelerinin kullanımı. Ekev Akademi Dergisi, 37, 385-392.

Yaşar, Ş. (1998). Eğitimde bilgisayarların etkili kullanımı. T.C. Anadolu Üniversitesi Yayınları Açıöğretim Fakültesi Yayınları, 1059(582), Eskişehir, 117-131.

Yestrebsky, C. L. (2015). Flipping the classroom in a large chemistry class-research university environment. Procedia - Social and Behavioral Sciences, 191, 1113-1118. https://doi.org/10.1016/j.sbspro.2015.04.370 